\title{
Effects of the menstrual cycle on rocuronium injection-related withdrawal movement
}

\section{Rokuronyum ilişkili geri çekme hareketi üzerine menstrual siklusun etkileri}

\author{
Sinan YILMAZ ${ }^{1 \oplus, ~ S e l d a ~ D E M I I R C A N ~ S E Z E R ~}{ }^{2}$ \\ ${ }^{1}$ Adnan Menderes Üniversitesi Tıp Fakültesi Hastanesi, Anesteziyoloji ve Reanimasyon Anabilim Dalı, Aydın, Türkiye \\ ${ }^{2}$ Adnan Menderes Üniversitesi Tıp Fakültesi Hastanesi, Kadın Hastalıkları ve Do ğum Anabilim Dalı, Aydın, Türkiye
}

\begin{abstract}
Objective: Pain and withdrawal movement after rocuronium injection are very frequently seen in clinical practice. In this prospective, double-blind study, we aimed to evaluate the effect of menstrual cycle on withdrawal movement due to rocuronium injection.

Methods: A total of one-hundred patients who will undergo elective surgery under general anesthesia were distributed evenly into Groups F (Follicular phase) and L (Luteal phase). Rocuronium-induced witdrawal movement was evaluated using a 4-point scale. This study is registered in the website (clinicaltrial.gov.)

Results: The rocuronium injection-related withdrawal movement (RIWM) score of the follicular Group 0 (0-1) was significantly lower than the score of the luteal Group $1(0-1.25)$ ( $p=0.001)$. Rocuronium- induced withdrawal movement score of the luteal group was higher than that of the follicular group. And also, there was an increase in hemodynamic parameters in the luteal group after rocuronium injection.

Conclusion: We determined that the rate of rocuronium injection-related withdrawal movement was higher in the luteal phase compared to the follicular phase. We also determined that the levels of the hemodynamic parameters were higher during the operation in patients in the luteal phase in whom the rate of withdrawal movement increased.
\end{abstract}

Keywords: Rocuronium, withdrawal movement, injection, menstrual cycle, general anaesthesia

$\ddot{\mathbf{o z}}$

Amaç: Rokuronyum enjeksiyonu sonrası ağrı ve geri çekme hareketleri, klinikte oldukça sık görülmektedir. Bu prospektif, çift kör çalışmada, menstruel siklusun rokuronyum enjeksiyon ağrısına etkisini değerlendirmeyi amaçladık.

Yöntem: Genel anestezi altında elektif cerrahi yapılacak 100 hasta çalışmaya alındı. Menstrual siklus fazlarına göre 50 hasta, Group F (Folikuler faz) ve 50 hasta group L (Luteal faz) olarak ikiye ayrıldı. Rokuronyum ilişkili geri çekme hareketi 4-nokta skalası ile değerlendirildi. Bu çalışma clinicaltrial.gov adresinde kayıtlıdır.

Bulgular: Folikuler grubun geri çekme skoru median 0 (0-1) luteal gruptan $1(0-1,25)$ anlamlı düşük saptandı $(p=0,001)$. Rokuronyum ilişkili geri çekme hareketi skorunun, luteal grupta folikuler gruptan yüksek olduğu saptandı. Ayrıca rokuronyum enjeksiyonu sonrası luteal grupta hemodinamik parametrelerde de artış saptadık.

Sonuç: Rokuronyum ilişkili geri çekme hareketinin luteal fazda folikuler faza kıyasla daha fazla oluştuğunu saptadık. Ayrıca operasyon sırasında çekilme hareketinin arttığı luteal fazdaki hastalarda, hemodinamik parametrelerde de yükselme olduğunu saptadık.

Anahtar kelimeler: Rokuronyum, geri çekme hareketi, enjeksiyon, menstrual siklus, genel anestezi
Alındığı tarih: 04.05.2018 Kabul tarihi: 17.06 .2018

Yazışma adresi: Yrd. Doç. Dr. Sinan Yılmaz, Adnan Menderes Üniversitesi Tip Fakültesi Anesteziyoloji ve Reanimasyon Bölümü, 09020 Aydın - Türkiye

e-mail: dr_snnylmz@hotmail.com

Yazarlarm ORCID bilgileri:

S.Y. 0000-0002-5281-137X 


\section{INTRODUCTION}

Rocuronium is a non-depolarizing, neuromuscular blocker agent with aminosteroid structure which has been frequently used in modern anesthesia in recent years ${ }^{(1)}$. Rocuronium-induced withdrawal movement (RIWM) is defined as sudden flexion of the wrist or arm for 5-10 seconds following the rocuronium infusion ${ }^{(2)}$. The incidence of rocuroniuminduced painful withdrawal movement has been reported to be within the range of $50 \%$ to $80 \%$ of the cases ${ }^{(3,4)}$.

In the experimental and epidemiological studies about the relationship between pain and gender, it has been stated that in women the perception and duration of pain increase, and the pain threshold is lower than men ${ }^{(5-7)}$. Several mechanisms have been asserted to be related to this condition. Hormonal fluctuations during the menstrual phase together with the expression levels of estrogen and progesterone receptors in the regions associated with pain located between central nervous system and spinal cord have been shown to be effective ${ }^{(5-7)}$.

The menstrual cycle is completed within 21-35 days (28 days in average) in general. During the follicular phase, increased estrogen level results in suppression of luteinizing hormone ( $\mathrm{LH})$; then, on the $12^{\text {th }}$ day following menstruation, LH level increases and reaches its peak level for approximately 48 hours, resulting in induction of ovulation. The luteal phase is the last phase of the menstrual cycle and lasts for 14 days in general ${ }^{(8)}$. There are conflicting results about the pain perception in women during follicular and luteal phases ${ }^{(9-11)}$. There are limited number of studies investigating RIWM in follicular and luteal phases ${ }^{(4)}$. We aimed to investigate the effects of luteal and follicular phases of menstrual cycle on RIWM in this prospective, randomized, and double-blind study.

\section{MATERIAL and METHODS}

This study was performed between January 2014 and January 2015. Ethical approval was obtained according to the procedures required for this prospective study (registration number of ethical code of Adnan Menderes University Faculty of Medicine: 2013/301). This study was registered with clinicaltrial.gov (code number NCT02539706). A total of 100 patients aged between 15 and 45 years (ASA physical status I-II) were included in the study. Informed consent was obtained from all patients. Patients with neurological or psychiatric disorders, menstrual irregularities, history of oral contraceptive use, amenorrhea, pregnancy, renal or hepatic dysfunction, total abdominal hysterectomy and/or bilateral salpingooophorectomy, hypersensitivity to the pharmacological agents that were used in the study together with patients who had refused to participate in the study were excluded from the study. The date of the last menstruation and the duration of menstruations were questioned and recorded. Patients with a menstruation period under 26 days or over 30 days were also excluded from the study. Patients were divided into 2 groups according to the phase of the menstrual cycle. The phases were defined according to the calendar method ${ }^{(12)}$, assuming the first day of the menstruation as the first day of the cycle. The follicular phase was considered as the interval between $8^{\text {th }}$ and $12^{\text {th }}$ days following the last day of the menstrual cycle whereas the luteal phase was considered to exist between $20^{\text {th }}$ and $24^{\text {th }}$ days. Each of the Groups F (Follicular phase) and L (Luteal phase) contained 50 patients.

Thirty minutes before the induction of anesthesia. $0.05 \mathrm{mg} / \mathrm{kg}$ midazolam (Demizolam) was administered intramuscularly to all patients. Venous catheterization was performed on the dorsal side of the hand using 20 gauge intravenous cannula in the operating room. Fentanyl ( $1 \mu \mathrm{g} / \mathrm{kg})$ and propofol $(2.5-3 \mathrm{mg} / \mathrm{kg})$ were used for anesthesia induction following standard monitoring of anesthesia. Rocuronium $(0.6 \mathrm{mg} /$ $\mathrm{kg}$ ) at the room temperature was injected within 8-10 seconds after the loss of consciousness was observed. The patients were observed for pain and the response was assessed by an anesthesiologist blinded to the study. The withdrawal movement was assessed by 
using a 4-point scale that was rated as follows: $0=$ no response, $1=$ movement of the wrist only, $2=$ withdrawal movement involving the arm only (elbow/shoulder) and $3=$ generalized response (withdrawal movement in more than one extremity, cough, and breath holding). Anesthesia was maintained using 50\% mixture of oxygen/nitrous oxide. Systolic blood pressure (SBP), mean arterial pressure (MAP) diastolic blood pressure (DBP) and heart rate (HR) were recorded in all patients before (BR) and after (AR) induction of anesthesia with rocuronium.

\section{Statistical Analysis}

At least 8 patients were included in each group to perform this research with effect size of 1.3, alpha value of 0.05 , and power rate of $85 \%$ for hand withdrawal movements score ${ }^{(4)}$. The KolmogorovSmirnov test was used to examine the normal distribution of quantitative data. The independent samples t-test was used to compare the data with normal distribution among the groups and the descriptive statistics were shown as mean \pm standard deviation. In the comparison of groups with data of non-normal distribution, the Mann-Whitney U or the Wilcoxon T test was used, and the descriptive statistics were expressed as median values $\left(25^{\text {th }}-75^{\text {th }}\right.$ percentiles $)$. A chisquare test was performed to analyze the categorical data, and descriptive statistics were presented as frequency (\%). P values under 0.05 were considered statistically significant.

\section{RESULTS}

The demographic and hemodynamic data of the patients were summarized in Table 1 . There was no statistically significant difference between the two groups in terms of the type of the operation, duration of the menstrual cycle and the menstruation phase ( $>0.05)$ (Table 1). There was no difference between the two groups in terms of SBP, MAP, DBP and HR values that were measured before rocuronium injection $(p>0.05)$ (Table 1$)$. The median $\left(25^{\text {th }}-75^{\text {th }}\right.$ percen- tile) withdrawal movement score of the follicular group $0(0-1)$ was determined to be statistically significantly higher that the score of the luteal group 1 $(0-1.25)(\mathrm{p}=0.001)$ (Table 1). The withdrawal responses to the rocuronium injection in the two groups are summarized in Table 2. The withdrawal response was not observed in $74 \%$ of the patients in the follicular group, and none of the patients developed a generalized movement. However, the withdrawal movement was observed in $62 \%$ of the patients in the luteal group $(\mathrm{p}<0.001)$ (Table 2).

There was no statistically significant difference in terms of hemodynamic parameters between follicular

Table 1. Demographic and hemodynamic parameters of the study groups and comparison results.

\begin{tabular}{|c|c|c|c|}
\hline & $\underset{(n=50)}{\text { Group F }}$ & $\underset{(\mathbf{n}=50)}{\text { Group L }}$ & $\underset{\text { value }}{\mathbf{p}}$ \\
\hline Age (years) & $30.4 \pm 8.3$ & $30.5 \pm 8$ & 0.932 \\
\hline Weight $(\mathrm{kg})$ & $65.1 \pm 13.2$ & $62.2 \pm 12.1$ & 0.254 \\
\hline $\begin{array}{l}\text { Usual menstrual cycle } \\
\text { length (days) }\end{array}$ & $28 \pm 1$ & $28 \pm 1$ & 0.282 \\
\hline $\begin{array}{l}\text { Usual menstruation } \\
\text { phase length (days) }\end{array}$ & $5 \pm 1$ & $5 \pm 1$ & 0.335 \\
\hline \multicolumn{4}{|l|}{ Type of Surgery } \\
\hline Rhinoplasty (n) & 5 & 8 & 0.866 \\
\hline Tympanoidectomy (n) & 12 & 7 & \\
\hline Adenotonsillectomy (n) & 4 & 4 & \\
\hline Septoplasty (n) & 9 & 11 & \\
\hline Breast surgery (n) & 9 & 8 & \\
\hline Functional Endoscopic & 5 & 4 & \\
\hline Sinus Surgery (n) & 6 & 8 & \\
\hline \multicolumn{4}{|l|}{ Others (n) } \\
\hline BR-SBP (mmHg) & $126.5(112.7-141.5)$ & $124(114.7-130.5)$ & 0.389 \\
\hline $\mathrm{BR}-\mathrm{MAP}(\mathrm{mmHg})$ & $93(85.7-104)$ & $94(86.7-99.5)$ & 0.407 \\
\hline $\mathrm{BR}-\mathrm{DBP}(\mathrm{mmHg})$ & $71(64-84)$ & $73.5(66-80.2)$ & 0.963 \\
\hline BR-HR (bpm) & $82(78.7-98)$ & $90(78.7-98)$ & 0.407 \\
\hline $\begin{array}{l}\text { Withdrawal movements } \\
\text { score }\end{array}$ & $0(0-1)$ & $1(0-1.25)$ & 0.001 \\
\hline
\end{tabular}

Group F=Women in the follicular phase of menstrual cycle, Group $L=$ Women in the luteal phase of menstrual cycle.

$B R-S B P=$ Before rocuronium-systolic blood pressure, $B R$ - $M A P=$ Before rocuronium-mean arterial pressure, $B R-D B P=$ Before rocuroniumdiastolic blood pressure, $B R-H R=$ Before rocuronium-hearth rate

Table 2. The comparison of the withdrawal movement following rocuronium injection between two groups.

\begin{tabular}{lccc}
\hline Withdrawal Response & Group F (\%) & Group L (\%) & p value \\
\hline No response & $37(74)$ & $19(38)$ & $<0.001$ \\
Movement at the wrist only & $13(26)$ & $19(38)$ & $<0.001$ \\
Movement withdrawal involving & $0(0)$ & $10(20)$ & $<0.001$ \\
arm only & $0(0)$ & $2(4)$ & $<0.001$ \\
Generalized response & & & \\
\hline
\end{tabular}


Table 3. Hemodynamic parameters of both two groups before and after rocuronium and comparison results.

\begin{tabular}{|c|c|c|c|c|c|c|}
\hline \multirow[b]{2}{*}{ Hemodynamic parameters } & \multicolumn{3}{|c|}{ Group F } & \multicolumn{3}{|c|}{ Group L } \\
\hline & $\mathrm{BR}$ & $\mathrm{AR}$ & $\mathrm{p}^{*}$ & $\mathrm{BR}$ & $\mathrm{AR}$ & $\mathrm{p}^{* *}$ \\
\hline $\mathrm{SBP}(\mathrm{mmHg})$ & $\begin{array}{c}126.5 \\
(112-141)\end{array}$ & $\begin{array}{c}108 \\
(100-126.2)\end{array}$ & $<0.001$ & $\begin{array}{c}124 \\
(114.7-130.5)\end{array}$ & $\begin{array}{c}129 \\
(104-138.2)\end{array}$ & 0.992 \\
\hline MAP & $\begin{array}{c}93 \\
(85.7-104)\end{array}$ & $\begin{array}{c}81.5 \\
(72.7-94.5)\end{array}$ & $<0.001$ & $\begin{array}{c}94 \\
(86.7-99.5)\end{array}$ & $\begin{array}{c}93.5 \\
(78.7-103.2)\end{array}$ & 0.854 \\
\hline DBP (mmHg) & $\begin{array}{c}71 \\
(64-84)\end{array}$ & $\begin{array}{c}62 \\
(55.7-71.7)\end{array}$ & $<0.001$ & $\begin{array}{c}73.5 \\
(66-80.2)\end{array}$ & $\begin{array}{c}75.5 \\
(66.7-80.7)\end{array}$ & 0.292 \\
\hline HR (bpm) & $\begin{array}{c}82 \\
(78.7-98)\end{array}$ & $\begin{array}{c}74.5 \\
(67-85.2)\end{array}$ & $<0.001$ & $\begin{array}{c}90 \\
(78.7-98)\end{array}$ & $\begin{array}{c}92 \\
(82.7-103.5)\end{array}$ & 0.015 \\
\hline
\end{tabular}

$B R=$ before rocuronium, $A R=$ after rocuronium, $S B P=$ systolic blood pressure, $D B P=$ diastolic blood pressure, $M A P:$ mean arterial pressure, $H R=$ heart rate, ${ }^{*} p=$ when group $F-B R$ compared to group $F-A R$, ** $p=$ when group $L-B R$ compared with group $L-A R$.

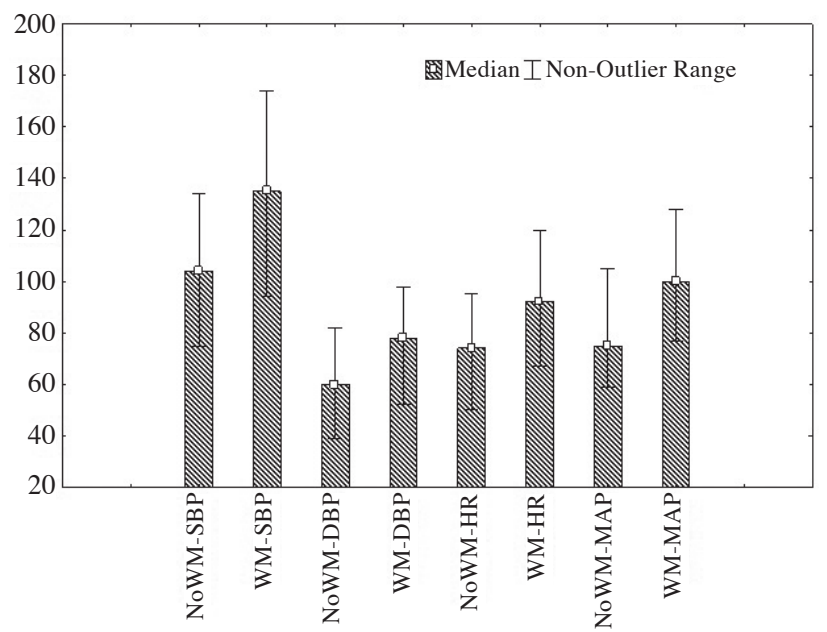

Figure 1a. The comparison of hemodynamic parameters in patients with or without withdrawal movement in the follicular group.

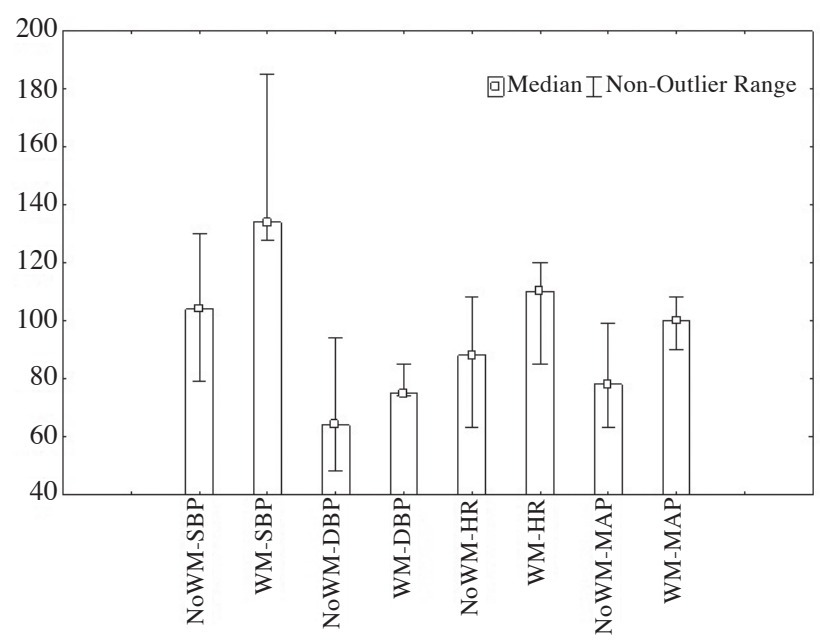

Figure 1b. The comparison of hemodynamic parameters in patients with or without withdrawal movement in the luteal group.

NoWM $=$ No withdrawal movements, $S B P=$ systolic blood pressure, $D B P=$ diastolic blood pressure, $H R=$ hearth rate and luteal groups before the rocuronium injection ( $p>0.05$ ). SBP, MAP, DBP and HR values were found to be significantly decreased after rocuronium injection and administration of general anesthesia in the follicular group $(\mathrm{p}<0.001)$. However, hemodynamic parameters were found to be increased after rocuronium injection and general anesthesia in the luteal group whereas increase in only HR was statistically significant in this group $(\mathrm{p}=0.015)$ (Table 3$)$.

The frequency of withdrawal movement following rocuronium injection was found to be $44 \%$ when all patients in the study were included $(n=44)$. AR-SBP, AR-MAP, AR-DBP and AR-HR values were found to be statistically significantly increased in patients demonstrating withdrawal movement in the follicular and luteal groups $(\mathrm{p}<0.001, \mathrm{p}=0.003$, $\mathrm{p}<0.001, \mathrm{p}<0.001, \mathrm{p}<0.001, \mathrm{p}<0.001, \mathrm{p}=0.016$, respectively) (Figure 1).

Withdrawal movement was found to be present 4.64 times more frequently in the luteal group compared to the follicular group when the effects of age, weight and the group parameters were assessed by multiple regression analysis (\%95 CI 1.98-10.88, $\mathrm{p}<0.001)$.

\section{DISCUSSION}

In this study, we determined that the rate of rocuronium-induced withdrawal movement (RIWM) increased in women in the luteal phase of the menstrual cycle compared to the follicular phase. 
Furthermore, in both study groups, hemodynamic parameters (SBP, MAP, DBP, and HR) were found to be higher in patients in whom withdrawal movements were present.

Rocuronium-related pain and withdrawal movement are very common and unwanted side effects of anesthesia practice ${ }^{(2-4)}$. There are several theories associated with the formation of this pain. It was asserted that acidic $\mathrm{pH}^{(4)}$ of the solution results in mast cell degranulation and activation of $\mathrm{C}$-nociceptors by the pain-related mediators (histamine, tryptase, and other inflammation-related mediators) which have been released due to mast cell degranulation ${ }^{(2-4)}$. However, in a recent study, it was demonstrated that rocuronium suppresses nitric oxide production and induces prostaglandin E2 synthesis in pulmonary artery endothelium cell culture and this mechanism was associated with this entity ${ }^{(1)}$. In our study, the rate of rocuronium-induced withdrawal movement was found to be lower (44\%) compared to the literature. Moreover, when the patients were reclassified according to the presence of RIWM, it was observed that AR-SBP, AR-MAP, AR-DBP and AR-HR measurements were significantly higher in RIWMpositive patients. We have asserted that activation of the sympathetic nervous system by pain may be related to the increase in hemodynamic parameters.

In a study assessing the relationship between the rocuronium injection site and pain, it was observed that the intensity of pain was higher in injections performed to the dorsal side of the hand compared to the injections performed to the antecubital vein. It has been asserted that this difference might be related to the higher acid solution buffering capacity of larger veins ${ }^{(3)}$. In order to avoid this difference, we performed the injection from the dorsal side of the hand in all of our patients.

Although a significant number of studies have been conducted on reducing the pain related to rocuronium injection, few studies have investigated the effects of menstrual cycle on the perception of pain ${ }^{(3,4)}$. In several studies, increased perception of rocuronium injection-related pain in women have been shown to be related to the low or reduced estradiol or progesterone levels, whereas in some other studies, it has been indicated that sex hormones are not related to the perception of pain ${ }^{(13-17)}$. It has been observed that estradiol supplementation resulted in a reduction of nociceptive response ${ }^{(18)}$. Furthermore, it has been also shown that estrogen was related to wellness and calmness while progesterone was related to inhibitory effects on neuronal activity ${ }^{(19)}$. The relationships between gonadal hormones and pain perception are complicated; however, the final effects of the ovarian hormones are related to their pro-nociceptive and anti-nociceptive effects ${ }^{(20)}$. In their study including 80 female patients, Honca et al. ${ }^{(4)}$ reported that the rocuronium-induced pain response is increased in patients in luteal phase compared to patients in the follicular phase. They indicated that the withdrawal movement was observed in $90 \%$ of the luteal group and this increased response was associated with increased progesterone levels. However, they indicated the lack of gonadal hormone level measurement as a limitation of their study ${ }^{(4)}$. In another study conducted on healthy female patients aged between 20-40 years, the phases of menstruation were defined based on hormone levels, and it was indicated that the pain inhibition was more effective during the ovulation phase compared to the early period of the luteal phase ${ }^{(11)}$.

In our study, the rate of RIWM was found to be significantly lower in the follicular phase $(26 \%)$ compared to the luteal phase (62\%). The follicular phase was defined based on calendar method as the days between $8^{\text {th }}$ and $12^{\text {th }}$ days following the last day of menstruation, independent from the hormone levels. However, we considered that the pain perception could be decreased in the presence of ovulation at the $12^{\text {th }}$ day in patients classified in the follicular group. Moreover, increased estrogen levels might be related to decreased perception of pain in the patients in the follicular group. Multivariate regression analysis revealed that the rate of rocuronium injection-related withdrawal movement was 4.64 times more frequent in the luteal group. Furthermore, when the levels of hemodynamic parameters were evaluated after admi- 
nistration of general anesthesia and rocuronium, they were found to be higher in the luteal group in which withdrawal movements were more common whereas significantly low levels were determined in the follicular group.

In our study, the menstruation phases (follicular, and luteal) were defined based on the calendar method. The lack of hormone level measurements in our study had a significant effect on the interpretation of the results. However, numerous studies published in the medical literature based on the calendar method guided us during the planning stage of our study. We assert that hormone level-based decision making should be performed regarding the menstrual phase and that it would be more appropriate to evaluate rocuronium injection-related withdrawal movement based on this classification ${ }^{(11)}$.

\section{CONCLUSION}

In our study, we determined that the rate of rocuronium injection-related withdrawal movement was reduced in the follicular phase compared to the luteal phase. We also determined that the levels of the hemodynamic parameters were higher during the operation in patients in the luteal phase where the rate of withdrawal movement increased.

\section{REFERENCES}

1. Baek SB, Shin MS, Han JH, Moon SW, Chang B, Jeon JW, et al. Rocuronium Bromide Inhibits Inflammation and Pain by Suppressing Nitric Oxide Production and Enhancing Prostaglandin E(2) Synthesis in Endothelial Cells. Int Neurourol J. 2016;20:296-303. https://doi.org/10.5213/inj.1632796.398

2. Zhang XM, Wang Q, Wang WS, Wang M. Large vein injection alleviates rocuronium-induced pain in gynaecologic patients. Anaesth Crit Care Pain Med. 201630. https://doi.org/10.1016/j.accpm.2016.03.010

3. Honca M, Purtuloglu T, Honca T, Sizlan A, Deniz S, Kose A, et al. Effects of the menstrual cycle on injection pain due to rocuronium. J Clin Anesth. 2013;25(5):399-402. https://doi.org/10.1016/j.jclinane.2013.02.007

4. Borgeat A, Kwiatkowski D. Spontaneous movements associated with rocuronium: is pain on injection the cause? $\mathrm{Br} \mathrm{J}$ Anaesth. 1997;79:382-3. https://doi.org/10.1093/bja/79.3.382

5. Fillingim RB. Sex, gender, and pain: women and men really are different. Curr Rev Pain. 2000;4:24-30. https://doi.org/10.1007/s11916-000-0006-6

6. Riley JL $3^{\text {rd }}$, Robinson ME, Wise EA, Price DD. A metaanalytic review of pain perception across the menstrual cycle. Pain. 1999;81:225-35. https://doi.org/10.1016/S0304-3959(98)00258-9

7. Unruh AM. Gender variations in clinical pain experience. Pain. 1996;65:123-67. https://doi.org/10.1016/0304-3959(95)00214-6

8. Speroff L, Glass RH, Kase NG. Regulation of the menstrual cycle. In: L. Speroff, R.H. Glass, N.G. Kase, editors. Clinical Gynecologic Endocrinology and Infertility. $6^{\text {th }}$ ed. Lippincott Williams \& Wilkins, Baltimore (MD); 1999. pp. 201-46.

9. Brynhildsen JO, Hammar J, Hammar ML. Does the menstrual cycle and use of oral contraceptives influence the risk of low back pain? A prospective study among female soccer players. Scand J Med Sci Sports. 1997;7:348-53. https://doi.org/10.1111/j.1600-0838.1997.tb00165.x

10. Hellström B, Anderberg UM. Pain perception across the menstrual cycle phases in women with chronic pain. Percept Mot Skills. 2003;96:201-11. https://doi.org/10.2466/pms.2003.96.1.201

11. Rezaii T, Hirschberg AL, Carlström K, Ernberg M. The influence of menstrual phases on pain modulation in healthy women. J Pain. 2012;13:646-55. https://doi.org/10.1016/j.jpain.2012.04.002

12. Tófoli GR, Ramacciato JC, Volpato MC, Meechan JG, Ranali J, Groppo FC. Anesthetic efficacy and pain induced by dental anesthesia: the influence ofgender and menstrual cycle. Oral Surg Oral Med Oral Pathol Oral Radiol Endod. 2007;103:e34-8. https://doi.org/10.1016/j.tripleo.2006.08.024

13. Hapidou EG, Rollman GB. Menstrual cycle modulation of tender points. Pain. 1998;77:151-61. https://doi.org/10.1016/S0304-3959(98)00087-6

14. Hellström B, Lundberg U. Pain perception to the cold pressor test during the menstrual cycle in relation to estrogen levels and a comparison with men. Integr Physiol Behav Sci. 2000;35:132-41. https://doi.org/10.1007/BF02688772

15. Kowalczyk WJ, Evans SM, Bisaga AM, Sullivan MA, Comer SD. Sex differences and hormonal influences on response to cold pressor pain in humans. J Pain. 2006;7:151-60. https://doi.org/10.1016/j.jpain.2005.10.004

16. Okifuji A, Turk DC. Sex hormones and pain in regularly menstruating women with fibromyalgia syndrome. J Pain. 2006; 7:851-9. https://doi.org/10.1016/j.jpain.2006.04.005

17. Tousignant-Laflamme Y, Marchand S. Excitatory and inhibitory pain mechanisms during the menstrual cycle in healthy women. Pain. 2009;146:47-55. https://doi.org/10.1016/j.pain.2009.06.018

18. Stoffel EC, Ulibarri CM, Craft RM. Gonadal steroid hormone modulation of nociception, morphine antinociception and reproductive indices in male and female rats. Pain. 2003;103:285-302. https://doi.org/10.1016/s0304-3959(02)00457-8

19. Kuhl H. Influence of the ovarian cycle on the central nervous system. Ther Umsch. 2002;59:175-81. https://doi.org/10.1024/0040-5930.59.4.175

20. Iacovides S, Baker FC, Avidon I, Bentley A. Women with dysmenorrhea are hypersensitive to experimental deep muscle pain across the menstrual cycle. J Pain. 2013;14:1066-76. https://doi.org/10.1016/j.jpain.2013.04.010 